\title{
KÖNYVTÁRI SZOLGÁLTATÁSOK - KÖNYVTÁRHASZNÁLÓK. ELVÁRT KOMPETENCIÁK A KISTELEPÜLÉSEKEN
}

\section{BÖRÖCZ LÍVIA}

\section{Tartalmi összefoglaló}

A vidékfejlesztési program részeként indult meg 2010-ben a vidéki alapszolgáltatások fejlesztése többfunkciós szolgáltató terek kialakítására az ún. IKSZT (Integrált Közösségi Szolgáltató Tér) pályázatok révén. 2010 és 2015 között 465 vidéki település integrált közösségi szolgáltatóhelye kezdte meg müködését az országban. A komplex kormányzati intézkedés keretében a vidéki kistelepülések kihasználatlan, leromlott infrastuktúrájú közösségi, közmüvelödési épületeit újitották fel. A program keretében a felújitás után a kistelepülések vállalták a megpályázott közösségi tevékenységek folyamatos fenntartását. A közösségi terekben dolgozó munkatársak - modern polihisztorként - az üzemeltetés ellátása mellett szociális, közmüvelödési és könyvtárosi feladatokat látnak el.

https://doi.org/10.46280/KOMPKONF.2020.Borocz

\section{Bevezetés}

A közösségi fejlesztések, az IKSZT-k működtetése és a könyvtári ellátás a kistelepüléseken egymást fedő, támogató folyamatok.

A vidéki térségekben, kistelepülések közösségi tereiben dolgozóknak (IKSZT munkatársaknak, könyvtárosoknak) egyfajta újkori polihisztorrá kellene válniuk. Hogy pontosan miért? Reméljük, az előadás végére kiderül!

\section{A Herman Ottó Intézet feladatairól és az IKSZT Programirodáról}

A Herman Ottó Intézet (korábban Nemzeti Agrárszaktanácsadási, Képzési és Vidékfejlesztési Intézet, NAKVI) a földművelésügyi tárca kibővült feladatkörű háttérintézménye, a névadójához hasonlóan nagyon sokféle feladattal foglalkozik: a közösségi, kulturális és gazdasági fejlesztések, valamint a kormányzati, civil és egyházi szervezetek közötti valós együttmüködések kialakítása mellett a hazai természeti értékek megőrzését, a környezet védelmét tekinti alapvető feladatának. Szakmai segítséget nyújt az európai uniós irányelvekhez és nemzetközi 
egyezményekhez kapcsolódó tevékenységekhez, jelentések előkészítéséhez, jogszabályok véleményezéséhez. Emellett folytatja legrégebbi felelősségi területének, az agrárszakképzésnek a gondozását, továbbá ellátja az intézetet érintő kiemelt programok és nemzetközi projektek menedzselését; ennek részeként koordinálja a szaktárca által meghirdetett Tanyafejlesztési Programot, valamint a Nemzeti Értékek és Hungarikumok pályázatot.

Annak érdekében, hogy az Integrált Közösségi és Szolgáltató Tér program sikeresen valósuljon meg, IKSZT programirodát működtet, amely szakmai, módszertani támogatást nyújt a címbirtokos szervezetek részére. A segítségnyújtás online (rendszeres hírlevél, honlap működtetése) és offline formában - a kisebb létszámú, frontális módszereket alkalmazó, akkreditált képzési programoktól (közösségi animátor képzés) a kisebb csoportos, nem-formális eseményeken át (Helyi Aktivációs Műhelynap), országos nagyrendezvényekig - valósul meg.

\section{Mi az az IKSZT?}

A 2007-2013-as időszak vidékfejlesztési programjának egyik legsikeresebb intézkedése volt a vidéki alapszolgáltatások fejlesztése többfunkciós szolgáltató terek által. A 2008-ban megjelenő Integrált Közösségi és Szolgáltató Tér (IKSZT) pályázati felhívást követően 2010 és 2015. között összesen 465 vidéki település Integrált Közösségi és Szolgáltató Tere, azaz IKSZT-je kezdte meg a müködését. Az adott közösségi tér megnyitását követően vette kezdetét a pályázathoz kapcsolódó öt éves fenntartás, amelyet a 2010-ben müködésüket megkezdők már a hátuk mögött tudhatnak, ám jellemzően a terek nagy részénél 2017-2018-ig, néhányan esetben 2020-ig tart ez az időszak.

Az IKSZT program előkészítése idején is látható volt, hogy ez a kezdeményezés az elmúlt évtizedek legjelentősebb vidéki közösségépítési és szolgáltatás-fejlesztési programja lesz. A sikeres megvalósítás előkészítése érdekében számos tapasztalt közösség- és vidékfejlesztő, népművelő dolgozott együtt, mindezt egy miniszterelnöki biztos támogatásával. A Földművelésügyi és Vidékfejlesztési Minisztérium döntéshozói és szakemberei körében világos volt már akkor is, hogy a vidékfejlesztés nem képzelhető el a helyi közösségek támogatása nélkül. A kezdeményezés alapvetően egy olyan komplex kormányzati intézkedést jelent, amely támogatást nyújt a vidéki kistelepülések többnyire kihasználatlan, leromlott infrastruktúrájú, korszerűtlen közösségi és közművelődési épületeinek felújítására, felszerelésére.

Az IKSZT azonban nem pusztán építkezés, hanem lehetőség arra, hogy a vidéki közösségek méltó környezetben élhessék meg hagyományaikat, teret kapjanak önszerveződő képességük kiteljesítéséhez, önmaguk folyamatos megújulásához. A program a hasonló korábbi kezdeményezésekre építve indult, felismerve azt, hogy a helyi közösségek megerősítése nélkül nem képzelhetö el semmilyen fenntartható társadalmi-gazdasági fejlesztés, hiszen mindehhez alapfeltétel, hogy a vidéki lakosok, főként a fiatalok ne vándoroljanak el. A kulturális kínálat, a szolgáltatások új szemléletű szervezése lehetőséget adhat a vidéki települések megújulására, a társadalmi összetartás erősítésére. 
Az első, 2010. október 15-én átadott úrhidai IKSZT-t a mai napig további 464 követte, így a támogatást elnyert 635 település több mint kétharmadán, immár 465 településen kezdte meg egy-egy IKSZT a müködését. A programban egy település legfeljebb 200 ezer euró öszszegben pályázhatott IKSZT kialakítására és müködtetésére. Az IKSZT programra pályázatot benyújtó szervezetek (települési önkormányzatok, egyházi szervezetek, civil szervezetek) a pályázat előkészítése során a programban kötelező, illetve a választható feladatokból egy helyi szolgáltatási portfóliót alakítottak ki, amely a kötelező fenntartási időszakban a minimum szolgáltatás az IKSZT részéről.

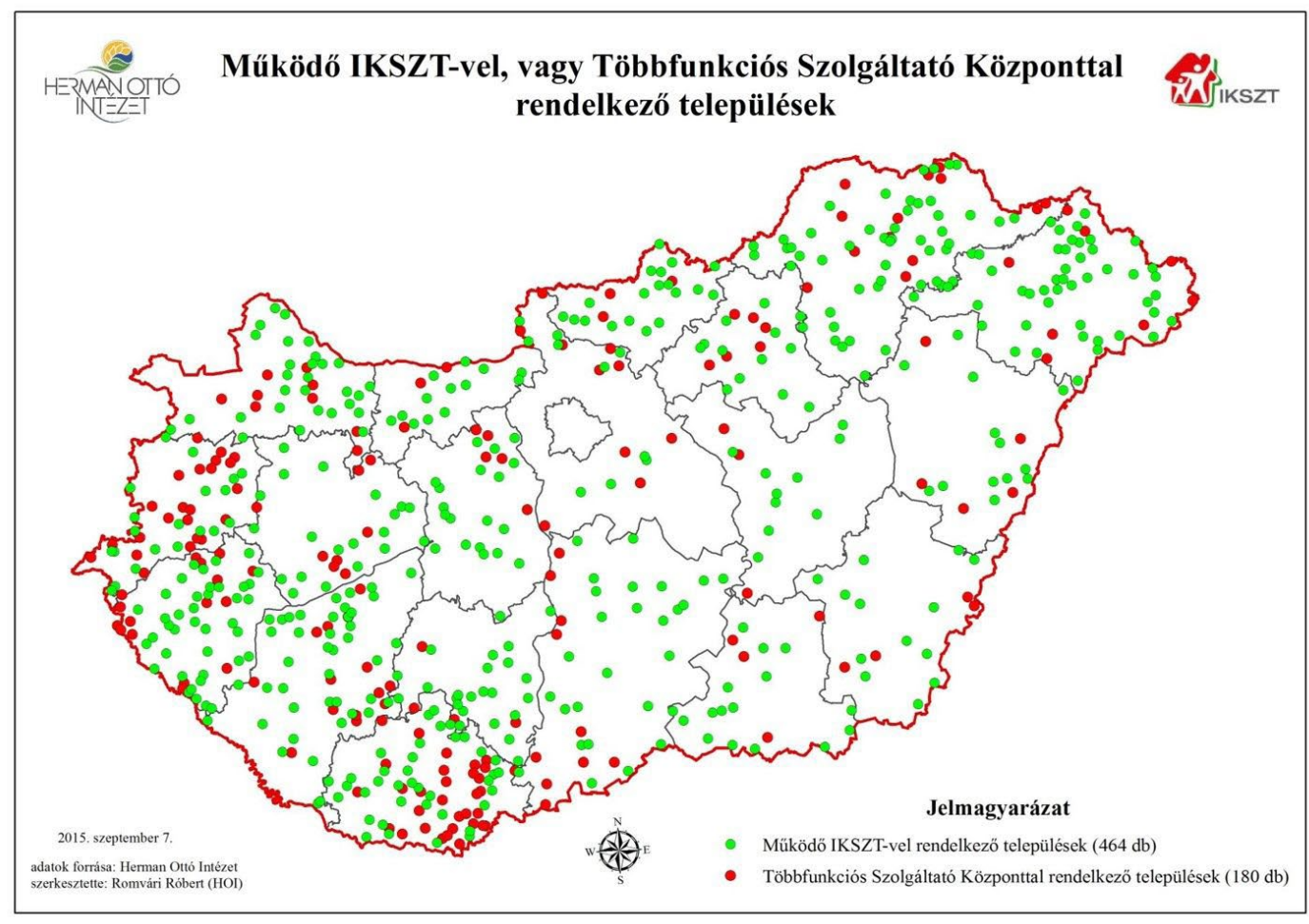

\section{Miért fontosak a szolgáltatások, milyen ember és kompetenciák szükségesek a feladatok ellátásához?}

Az IKSZT megnyitását megelőző helyi tervezés elengedhetetlen volt a szolgáltatási paletta kialakításához, amely az alábbi kötelező és választható tevékenységekből volt összeállítható. A program célja, hogy a kiválasztott tevékenységek folyamatos biztosításával a támogatásból megújult és korszerüen felszerelt közösségi tér (faluház, művelődési ház, teleház, vagy ahogyan a helyiek nevezik) a helyi igényekhez igazodva hozzájáruljon a vidéki települések életminőségének megtartásához, esélyeik növeléséhez. Mindezért a közösségi terekben dolgozó munkatársak ideális esetben a helyi közösségben elfogadott személyek, akik bátorítóan hatnak a lakosság körében induló kezdeményezésekre, régi-új szokások felelevenítésére. A szolgáltatások biztosításában aktívan részt vesznek, hiszen egy-egy kistelepülési IKSZT 
szerény munkatársi állománnyal gazdálkodhat - a legtöbb helyen egy fö látja el az összes feladatot - egy kicsit mindenhez szükséges érteniük. Minderre egyrészt az intézet közösségi animátor képzése, másrészt a helyi értékekre és környezetre nyitott, valamint a partnerekkel való együttműködés valódi mintája készíti fel az IKSZT munkatársakat.

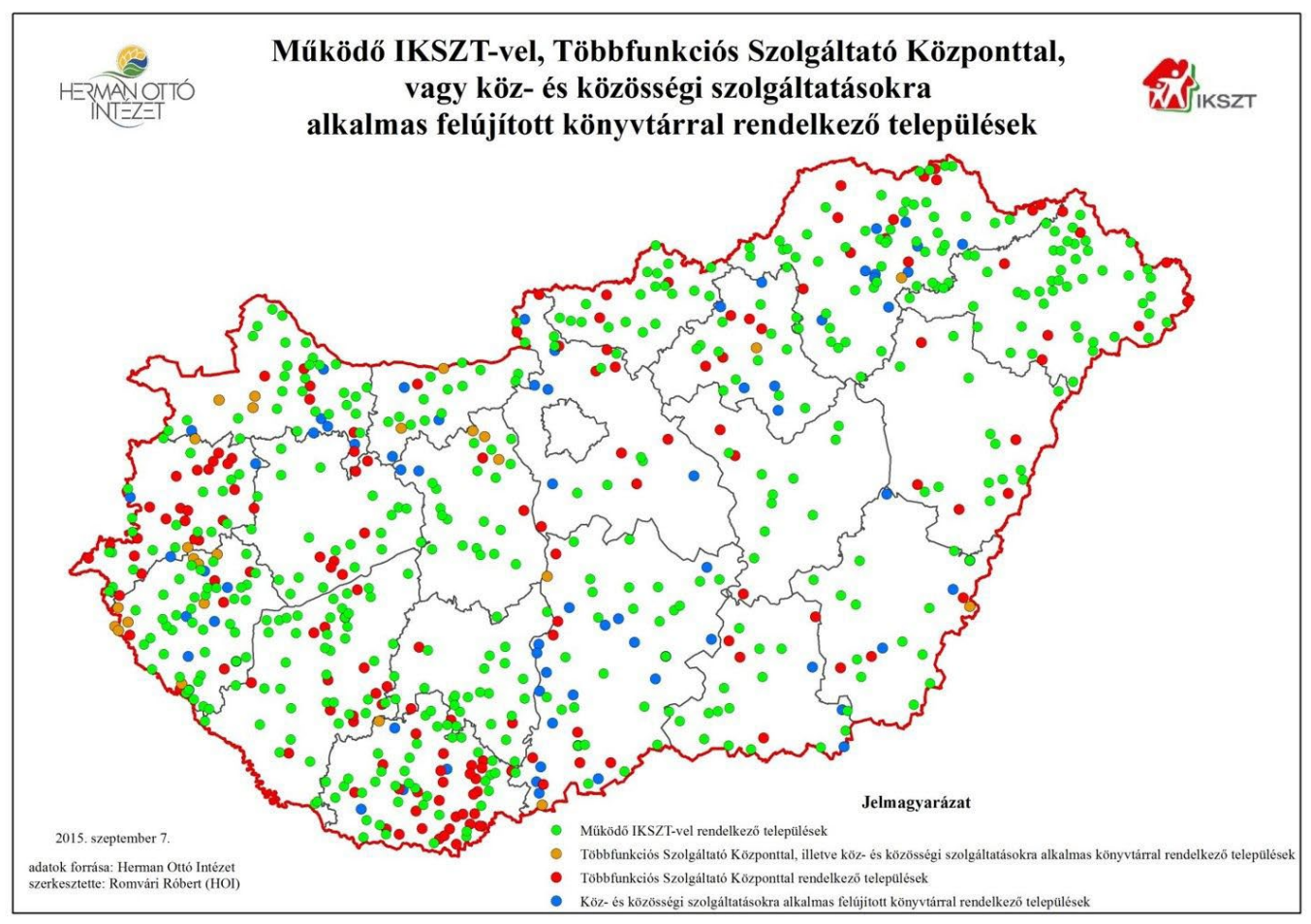

Az Integrált Közösségi és Szolgáltató Tér kötelező szolgáltatásai

a) helyszín és feltételek biztosítása a Magyar Nemzeti Vidéki Hálózat (MNVH) tájékoztatási valamint ügyfélszolgálati pont müködtetéséhez,

b) ifúuági közösségi programok szervezése, ifúságfejlesztési folyamatok generálása és folyamatkövetése, ifjúsági információs pont müködtetése,

c) a lakosság és a vállalkozások számára az információhoz való hozzájutás elősegítése (közösségi térben),

d) közösségi internet-hozzáférés biztosítása,

e) könyvtári és információs szolgáltatások biztosítása,

f) közművelődési programok szervezése.

Az Integrált Közösségi és Szolgáltató Tér választható szolgáltatásai

a) közösségfejlesztési folyamatok generálása, folyamatkövetése, helyszín biztosítása civil szervezetek számára,

b) tanoda tér/helyiség kialakítása,

c) gyermekek (különösen a 0-5 éves korosztály) foglalkoztatását biztosító tér/helyiség kialakítása, csatlakozás a biztos kezdet programhoz, 
d) egészségfejlesztési programok,

e) üzlethelység kialakítása a helyi vállalkozások támogatása érdekében,

f) postai szolgáltatás nyújtása,

g) elektronikus közigazgatási végpont szolgáltatása,

h) Állami Foglalkoztatási Szolgálat (ÁFSZ) információs pont (később NFSZ).

A rendkívül sokféle szolgáltatás megvalósításához csak úgy tud az IKSZT Programiroda segítséget nyújtani, ha az adott területért felelős szakmai szervezetekkel kapcsolatban van, folyamatos a kölcsönös tájékoztatás és együttmüködés. Ennek érdekében az intézet folyamatosan bővítette partnereinek körét: a különböző tárcák háttérintézményeivel, egyházi szervezetekkel, valamint országos hatókörü szakmai munkát végző civil szervezetekkel müködik hol formálisan, hogy projektszerüen együtt.

\section{Az IKSZT program és a könyvtár kapcsolata}

Az IKSZT-k egyik kötelező funkciója a könyvtári szolgáltatás, melynek a megfelelő szakmai-módszertani segítése érdekében, 2014-ben a III. Országos IKSZT Találkozón került sor az Informatikai és Könyvtári Szövetséggel, valamint a Könyvtári Intézettel együttmüködési megállapodás aláírására a Herman Ottó Intézet (akkor még NAKVI) részéről. Az együttmüködésnek köszönhetően jelentősen javult a szolgáltatás színvonala, olcsóbban tudnak könyveket rendelni, könnyebben tudnak elhívni kortárs írókat, közéleti személyiségeket.

\section{Összegzés}

Az Integrált Közösségi és Szolgáltató Tér (IKSZT) program megvalósítása során az országban 2008-2015 között, közel ötszáz, ötezer fő alatti településen egy újszerű szolgáltatási modell jött létre. Ezekben a közösségi terekben dolgozó munkatársaknak a legtöbb esetben egyfajta újkori polihisztorként kell müködniük: a ház üzemeltetésétől kedve a sokrétű szolgáltatások biztosításán át - amely elsősorban a szociális, közművelődési, vidékfejlesztési, könyvtáros, eTanácsadó, pedagógus, gazdasági területeket érinti - az adott kistelepülés lelkeként, közösség motorjaként funkcionálnak. Mindezt a legnagyobbrészt középfokú végzettséggel. 


\section{Irodalom}

BEKE Márton - DITZENDY Károly Arisztid: Integrált közösségi és szolgáltató terek. Módszertani kézikönyv. Budapest, HROD Emberi Erőforrás és Szervezetfejlesztés Kft. 2008. 154 p.

Forrás: http://mek.oszk.hu/07900/07917/07917.pdf [2018. október 31.]

EPERJESI Tamás előadási anyagai: https://docplayer.hu/7627911-Az-integralt-kozossegi-es-szolgaltato-ter-ikszt-program.html [2018. október 31.]

http://www.mut.hu/?module=news\&action $=$ getfile\&fid $=192013$

www.ikszt.hu [2018. október 31.]

www.nakvi.hu [2018. október 31.]

Böröcz Lívia 2004-2011 között ifjúsági referens Pécsváradon. 2012-től a Mobilitás Ifjúsági Szolgálatnál koordinációs referens. 2013-2017 júliusa között a Nemzeti Agrárszaktanácsadási, Képzési és Vidékfejlesztési Intézetnél (jelenleg Herman Ottó Intézet) az IKSZT programiroda munkatársaként dolgozott. 2017 augusztusától 2018. december végéig az NMI Müvelődési Intézet hálózati igazgatóságának igazgatóhelyettese, a 19 megyei iroda hálózati koordinátora. Részt vett a közmüvelődés szakpolitikáját, fejlesztési irányait meghatározó országos stratégiai program kidolgozásában, megvalósulásában. A konferencia idején a Herman Ottó Intézet Közösségi Fejlesztésekért és Értékraktárakért Felelős Osztályának vezetője volt. 